\title{
REVIEW OF STUdies ReLATED TO QUALITY ENTREPRENEURSHIP (I.E. INNOVATION AND INTERNATIONALIZATION) AS OUTCOMES OF EnTREPRENEURIAL NetWorking
}

Muhammad Umer Shahid*

BA School of Business and Finance

Riga,

Latvia

Umer.zai1988@gmail.com

Hab oec Vulfs Kozlinskis

Riga International School of Economics and Business Administration

Riga,

Latvia

vulfs.kozlinskis@riseba.Iv

*Corresponding Author email: Umer.zai1988@gmail.com

Submission: 12 January 2021

Revised: 20 February 2021

Accepted: 11 March 2021

Peer-review under responsibility of 6th Asia International Conference 2020 (Online) Scientific Committee http://connectingasia.org/scientific-committee/

(C) 2027 Published by Readers Insight Publisher, Office \# 6, First Floor, A \& K Plaza, Near D Watson, F-10 Markaz, Islamabad. Pakistan, editor@readersinsight.net This is an open access article under the CC BY license (http://creativecommons.org/licenses/4.0/). 


\section{A B S T R A C T}

Research in entrepreneurial networking has mainly elucidated the processes of recognizing various entrepreneurial opportunities. Studies on entrepreneurial networking have defined a network construct in different ways to explain various outcomes. So, the underlying idea is to explain which different entrepreneurial network compositions have been applied and what various network outcomes were achieved in general and quality entrepreneurship as outcome in specific. By conducting a comprehensive literature review an effort is made to form different set of clusters for a network construct and its outcomes based on how it is measured in several studies. Specifically, along with highlighting the network constructs the research in context of quality entrepreneurship as an outcome of entrepreneurial networking is explained in detail and directions for the future avenues are highlighted.

Keywords: Entrepreneurial Networking, New Ventures or Startups, Nascent Entrepreneurs

\section{R E S E A R C H H I G H L I G H T S}

- Research on networking dates back to early 1930's and since its inception the field of entrepreneurship has observed a significant increase in the studies related to networks and its relations (Jack, 2010). Indeed, a growing scholarly interest related to the role of networks in the very recent years has gained momentum while explaining its relationship with individuals, groups and organizations (Nedkovski et al., 2020; Horak et al., 2019; Keller et al., 2020).

- Surprisingly, the claim has been made regarding entrepreneurial networks stating that "they are reshaping the architecture of a global business" (Parkhe et al., $2006 \mathrm{p}$. 560). In this case it highlights the importance of understanding theoretical and practical implications associated with entrepreneurial networks.

- From this systematic literature review a detailed information is extracted highlighting the clusters for network construct as an independent variable.

- Mot of the research in the context of entrepreneurial network studies have focused on explaining their impact on performance (Jack, 2010) but various other outcome clusters for entrepreneurial network have also been formulated from this review. 


\section{G R A P H I C A L A B S T R A C T}

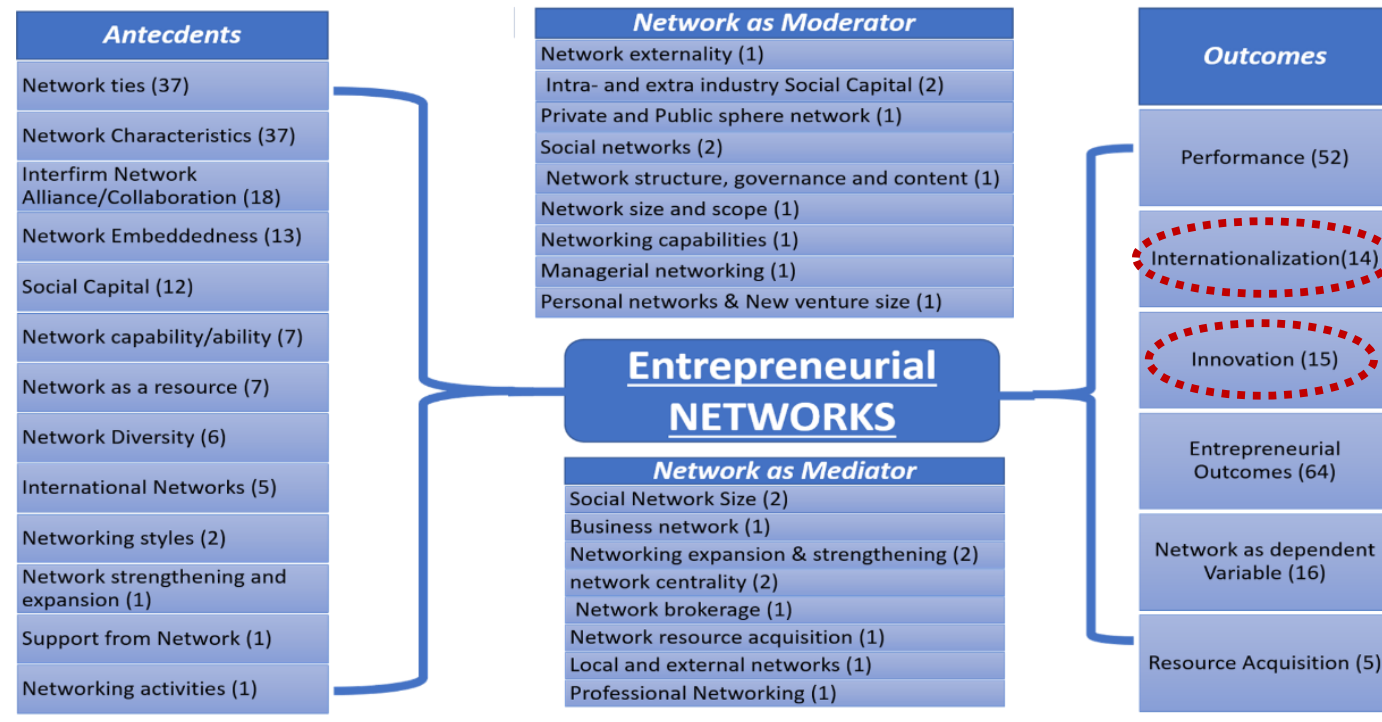

Fig A: Entrepreneurial Network Antecedents and Outcomes in General

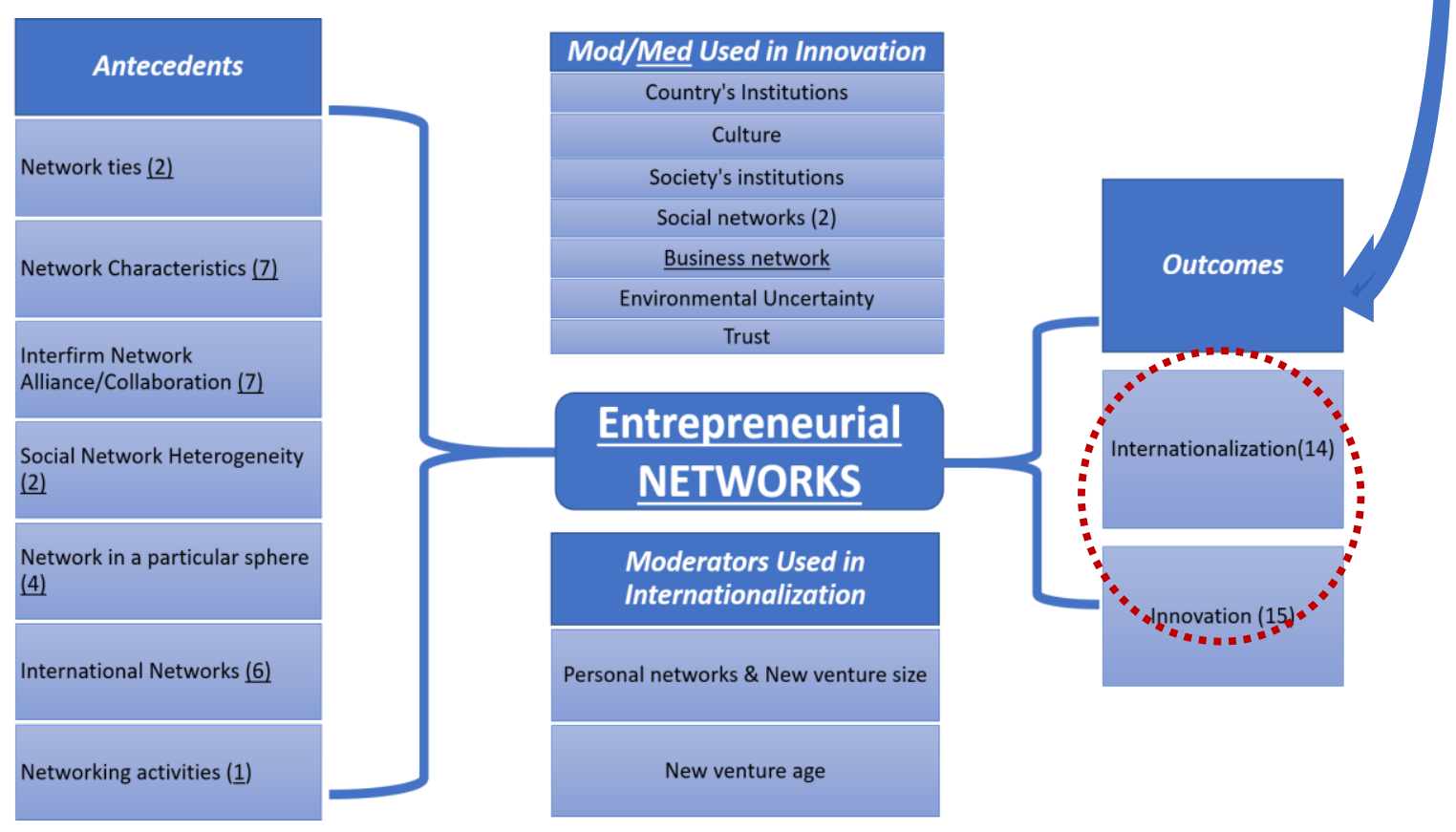

Fig B: Entrepreneurial Networks Antecedents and Quality Entrepreneurship as Outcome

While studying entrepreneurial network construct various outcomes achieved can be thought of as critical indicators for the entrepreneurial processes. Apart from entrepreneurial outcomes (such as growth, success, creation etc.) and performance as an important consequences some other aspects of entrepreneurial networking outcomes are also emerging like innovation (Burt, 2019; Schøtt, 2018) and internationalization (Karami and Tang, 2019; Ripollés and Blesa, 2017; Prashantham and Dhanaraj, 2015) as well. 


\section{Research Objectives}

Objective of study is to develop an integrated research model that explains the antecedents and outcomes of entrepreneurial networks used by entrepreneurs. In other words, the model explains "Which entrepreneurial network constructs as an antecedents are used to explore various outcomes (more specifically quality entrepreneurship indicators)". Therefore, combination of terms Network or ties or embeddedness AND new venture or startups or entrepreneurial were used to identify peer-reviewed journal articles. One of the significant contribution of this research is the development of clusters for entrepreneurial network and its outcomes based on how they are measured in a particular study. And the study provides insights on various indicators used to define a network construct and how these varying constructs have been used in the field to explain various outcomes.

\section{Methodology}

- The prominent business management data sources namely Clarivate Analytics's Web of Science and EBSCO Host were used to generate the initial set of articles.

- In order to focus on the search results, keyword observation was restricted to title and abstract of the study and the abstracts were reviewed to ensure relevance to the focus of networks in the context of new venture or startups or entrepreneur. The study was selected if the keywords [Network (Networks and Networking) or ties or embeddedness AND new venture or startups or entrepreneurial or entrepreneur] in combination were found in the study.

- Final body of knowledge comprised of 284 articles out of which 166 are quantitative studies and 118 qualitative studies respectively. But our research is focused specifically on the dimension of empirical studies therefore, for further review only explanation for quantitative studies were considered.

\section{Results}

The results of systematic literature review is explained as follows:

- The distribution of network clusters as an independent variable used in the literature includes, Network ties (37, studies), Network Characteristics (37, studies), Interfirm Network Alliance or Collaboration (18, studies), Network Embeddedness (13, studies), Social Capital (12, studies), Network capability/Ability (7, Studies), Network as resource (7, Studies), Network diversity (6, studies), International networks (5, studies), Networking styles (2, studies), Network strengthening and expansion (1, study), Support from network (1, study), Networking activities (1, study).

- Detailed information is extracted regarding various outcome clusters (dependent variable) of entrepreneurial network. Such that Performance as an outcome includes (52 studies), and various determinants of Entrepreneurial Outcomes includes (64 studies) along with five studies of resource acquisition. 
- Similarly, in the context of quality entrepreneurship indicatiors, internationalization comprised of 14 studies and innovation with 15 studies as dependent or outcome variable was observed.

- While studying the context of entrepreneurial networking various indicators of network characteristics (size, centrality, density, diversity) and network ties have been predominantly used to explain various outcomes however, on the other hand international networks and networking activities and styles have been understudied.

\section{Findings}

- Studies on network as antecedents of quality entrepreneurship indicators have mostly discussed the direct relationship but the moderation of country level effects have been understudied. Because networking activity is also effected by the indicators of a broader environment as well.

- A theoretical linkage between networks and institutions as a moderator is found missing therefore it is needed to establish and comprehend how the formal and informal institutions interact to affect innovation and internationalization.

- Few networks clusters like support from networks, networking activities, network strengthening and support are the least tapped clusters when it comes to studying the network context.

- Further there is also a need to examine whether these different clusters have some significance when it comes to analyzing some of its outcomes or not.

- Considering the significance of entrepreneurial networking there is possible future avenue to explore the impact of organizational level networking and its impact on various high-quality drivers of entrepreneurship. For e.g. networks offered by public sector actors (such as municipal entrepreneurial agencies) and private such as investors, services which the entrepreneurs are buying from other private sector actors (e.g. business mentoring, trainings, advices from banks etc) are very interesting avenues to study the differences between these kind of networks offered either by private or public sector actors.

\section{References}

Burt, R. S. (2019). Network disadvantaged entrepreneurs: Density, hierarchy, and success in China and the West. Entrepreneurship Theory and Practice, 43(1), 19-50.

Horak, S., Taube, M., Yang, I., \& Restel, K. (2019). Two not of a kind: Social network theory and informal social networks in East Asia. Asia Pacific Journal of Management, 36(2), 349-372.

Jack, S. L. (2010). Approaches to studying networks: Implications and outcomes. Journal of Business Venturing, 25(1), 120-137.

Karami, M., \& Tang, J. (2019). Entrepreneurial orientation and SME international performance: The mediating role of networking capability and experiential learning. International Small Business Journal, 37(2), 105-124. 
Keller, J., Wong, S.-S., \& Liou, S. (2020). How social networks facilitate collective responses to organizational paradoxes. Human Relations, 73(3), 401-428.

Nedkovski, V., Guerci, M., \& Carollo, L. (2020). Exploring the Role of Negative Relationships in Social Networks on Individuals' Innovative Behavior. Academy of Management Proceedings, 2020(1), 21171. Academy of Management Briarcliff Manor, NY 10510.

Parkhe, A., Wasserman, S., \& Ralston, D. A. (2006). New frontiers in network theory development. Academy of Management Review, 37(3), 560-568.

Prashantham, S., \& Dhanaraj, C. (2015). MNE ties and new venture internationalization: Exploratory insights from India. Asia Pacific Journal of Management, 32(4), 901924.

Ripollés, M., \& Blesa, A. (2017). Entry mode choices in the international new ventures context. A study from different theoretical perspectives. International Entrepreneurship and Management Journal, 13(2), 465-485.

Schøtt, T. (2018). Entrepreneurial pursuits in the Caribbean diaspora: networks and their mixed effects. Entrepreneurship \& Regional Development, 30(9-10), 1069-1090. 